\title{
Uncommon disorders and decay in near-isogenic lines of melon and reference cultivars
}

\author{
Juan Antonio Martínez'; Mohammad-Madi Jowkar²; Javier Mauricio Obando-Ulloa ${ }^{3}$; Plácido Varó ${ }^{4}$; \\ Eduard Moreno ${ }^{5}$; Antonio José Monforte ${ }^{6}$; Juan Pablo Fernández-Trujillo ${ }^{3 *}$ \\ ${ }^{1}$ Technical University of Cartagena (UPCT)-Dep. of Plant Production, Campus Paseo Alfonso XIII 48, ETSIA and Institute of Plant \\ Biotechnology, 30203 Cartagena (Murcia), Spain; ${ }^{2}$ Islamic Azad University, Kermanshah Branch, Baghe-ney, Kermanshah, Iran; ${ }^{3}$ UPCT- \\ Dep. of Agricultural and Food Engineering, ${ }^{4}$ Centro Integrado de Formación y Experiencias Agrarias (CIFEA)-Consejería de Agricultura \\ y Agua de la Región de Murcia, Av ${ }^{\mathrm{da}}$-Gerardo Molina, s/n, 30700 Torre Pacheco (Murcia), Spain, ${ }^{5}$ IRTA-Centre de Recerca en Agrige- \\ nòmica CSIC-IRTA-UAB, Ctra de Cabrils, km 2, 08348 Cabrils (Barcelona), Spain; ${ }^{6}$ Instituto de Biologia Molecular y Celular de Plantas \\ (IBMCP), Universidad Politécnica de Valencia (UPV)-Conxejo Superior de Investigaciones Cientificas (CSIC). juanantonio.martinez@ \\ upct.es; mjowk@yahoo.co.uk; juanp.fdez@upct.es; placido.varo@carm.es; amonforte@ibmcp.upv.es
}

\begin{abstract}
Postharvest disorders and rots can produce important economic losses in fruits stored for long time for exportation. The genetic and physiological basis of some disorders in melon (Cucumis melo L.) are unknown and particularly the possible relation with climacteric behavior. A collection of melon near-isogenic lines (NILs) (SC3-5 and seven more showing climacteric and two non-climacteric ripening pattern) were analyzed to study genetic and physiological aspects of fruit disorders and rots. Two non-climacteric (Nicolás; Inodorus Group; and Shongwan Charmi PI161375, Conomon Group) and two climacteric cultivars (Fado, Reticulatus Group; Védrantais, Cantaloupensis Group) were used as reference. The field was divided in eight blocks containing one three-plant replication for each NIL, two for the parental cultivar Piel de Sapo and one or two for the reference cultivars. Replications evaluated were more than six in the cultivars studied. Plant problems included aphids, powdery mildew, and leaf wind injury. Preharvest fruit disorders included whole fruit cracking in cultivar Védrantais and NIL 5M2, and stylar-end cracking in cultivar Fado. Climacteric NILs with yellow skin were particularly affected by over-ripening, stylar-end cracking, and sunburn during cultivation. At harvest, two NILs showed slight placental tissue necrosis which was inherited from SC and were also detected after storage. Other uncommon disorders seen at harvest or 30 days after storage at $8^{\circ} \mathrm{C}$ included warted skin (scarring), flesh discoloration (light brown or translucent areas), hollow flesh disorder, and deep furrow netting inherited from SC. Less common rots included grey mould, bacterial soft rot, Penicillium rot, cottony leak and internal Cladosporium rot. Stylar-end hardness below $20 \mathrm{~N} \cdot \mathrm{mm}^{-1}$ was associated with cracking and softening. The incidence of the disorders and rots was too low to confirm that the genetic component played a role in their development.
\end{abstract}

Keywords: Cucumis melo, decay, fruit quality, physiological disorders, postharvest, preharvest.

\section{RESUMO}

Acidentes fisiológicos e podridões atípicas em linhas quaseisogénicas de melão e em cultivares de referência

Analisaram-se frutos de melão (Cucumis melo L.) provenientes de uma coleção de linhas quase-isogénicas (NIL), SC3-5 e outras sete climatéricas e duas não-climatéricas, para avaliar a ocorrência de acidentes fisiológicos e a suscetibilidade a podridões. Como termo de comparação utilizou-se duas cultivares não-climatéricas (Nicolás, grupo Inodorus, e Shongwan Charmi ou acesso PI161375, grupo Conomon) e duas cultivares climatéricas (Fado, grupo Reticulatus, e Védrantais, grupo Cantaloupensis). O experimento foi dividido em oito blocos contendo três plantas por repetição para NIL, dois para a cultivar parental Piel de Sapo (PS), e um ou dois para a cultivar testemunha. As repetições avaliadas foram mais de seis para as cultivares em estudo. Durante a produção, as folhas foram afetadas por pulgão, oídio e acidentes meteorológicos. Os acidentes fisiológicos que ocorreram nos frutos durante a produção incluíram fendilhamento na cultivar Védrantais e na NIL 5M2 e fendilhamento da zona pistilar na cultivar Fado. As NIL climactéricas com casca amarela revelaram-se muito suscetíveis à sobre-maturação, fendilhamento pistilar e queimaduras solares durante a produção. Duas NIL exibiram uma ligeira necrose do tecido placentar, carater herdado da linha PI161375. Outros acidentes fisiológicos atípicos observados na colheita ou após 30 dias a $8^{\circ} \mathrm{C}$ incluíram casca verrugosa, descolorações castanho-claras na polpa, translucência da polpa, cavidades na polpa e ornamentação profundamente sulcada na casca, herdada do PI161375. Observou-se a ocorrência de podridões pouco usuais em melão, nomeadamente podridão cinzenta, podridão bacteriana, Penicillium sp., Phytium sp. e cladosporiose interna. Uma dureza da região pistilar inferior a $20 \mathrm{~N} \mathrm{~mm}-1$ estava associada ao fendilhamento e ao amolecimento excessivo. A ocorrência destes acidentes fisiológicos ou podridões foi baixa para assegurar o envolvimento de fatores genéticos no seu desenvolvimento.

Palavras-chave: Cucumis melo, qualidade do fruto, acidentes fisiológicos, podridão, pós-colheita, pré-colheita.

(Recebido para publicação em 18 de setembro de 2008; aceito em 27 de novembro de 2009) (Received in September 18, 2008; accepted in November 27, 2009)

$\mathrm{D}$ uring recent years, melon export from Brazil has increased dramatically in terms of quantity and cultivar diversity (Sales et al., 2004; Souza et al., 1994; Nunes et al., 2005). Although most of common occurring pests during plantation and fruit growth and development have been characterized (Zitter, 1986; Zitter et al., 2004), and most disorders associated with muskmelon development and shipment are well-known (Ceponis et al., 1986; Snowdon, 1991; Cantwell \& Portella, 1998;), still many questions concerning less common disorders 
and their possible genetic component (whether they act alone or interact with decay) remains.

A collection of near isogenic lines (NILs) derived from a cross between the Spanish Piel de Sapo control genotype (PS, Inodorus Group) and the exotic Korean accession Shongwan Charmi (SC), PI161375 has recently been developed (Eduardo et al., 2005). It is assumed that the parental lines of the mentioned cross (SC and PS) can be useful for studying melon preharvest and postharvest disorders (Périn et al., 2002; Eduardo et al., 2007; Fernández-Trujillo et al., 2007), as well as possible disease resistance (Morales et al., 2005).

The NIL collection including NIL SC3-5 and other NILs with shorter introgressions in linkage group (LG) III have revealed to be very useful in identifying QTLs responsible for several major postharvest disorders, including the link between susceptibility to disorders and climacteric behavior (Fernández-Trujillo et al., 2007, 2008). These NILs also contain QTLs responsible for fruit quality and aroma traits (Eduardo et al., 2007; Obando et al., 2008; Obando-Ulloa et al., 2008) that are being used for melon qualityoriented breeding programs. Previous reports indicated that shelf-life and ethylene production are inversely correlated (Zheng \& Wolf, 2000). In fact, negative genetic correlation has been reported between major skin injuries or rots and climacteric behavior (Fernández-Trujillo et al., 2008).

The aim of this paper was to describe some uncommon preharvest and postharvest disorders of a set of near-isogenic melon lines and reference cultivars. (Périn et al., 2002; Obando et al., 2007; Fernández-Trujillo et al., 2008; Moreno et al., 2008; ObandoUlloa et al., 2008;). In this paper, possible link between differences in cultivars, climacteric behavior and the occurrence of disorders and decay is especially emphasized.

\section{MATERIAL AND METHODS}

Plant material - the original parental lines for the near-isogenic lines population were the Cucumis melo L. Inodorus Group Piel de Sapo (PS) and the exotic Korean accession Shongwan Charmi of the Conomon Group (SC). The development scheme of the NILs, through repeated backcrossing and molecular markers assisted selection, has been previously reported (Eduardo et al., 2005). The NIL SC3-5ab was used to generate derived NILs with fewer introgressions by backcrossing with PS and molecular marker assisted selection (Eduardo et al., 2007). Line SC3-5 was a NIL similar to SC3-5ab (Eduardo et al., 2007). Nine NILs with fewer introgressions than SC3-5 were obtained ( $5 \mathrm{Mx}, \mathrm{x}=2$ to 10 ). These NILs were also climacteric, except for 5M2 (not measured, but without the signs of skin color turning from green to yellow, which is typical of climacteric NILs) and the non-climacteric 5M7.

Commercial cultivars used as reference were cultivar Fado F1, Reticulatus Group (a Galia type from Semillas Fitó); an F1 hybrid of cultivar Nicolás (Syngenta Seeds, Torre Pacheco, Murcia); and the parental cultivar Védrantais, Cantaloupensis Group, (Vilmorin Clause \& Cie, La Menitre, France).

Experimental design - seeds were sown in seed plugs (plug trays) on March 9, 2005, and seedlings were hand-transplanted on April 12 to an experimental field located at Torre Pacheco (Murcia, Spain). The whole plot had $1,566 \mathrm{~m}^{2}$, divided into 18 single rows, all covered with black plastic mulch $1.1 \mathrm{~m}$ wide and $22.9 \mu \mathrm{m}$ thick. Planting distances were $2 \mathrm{~m}$ between rows and $1.5 \mathrm{~m}$ within plants from the same row.

A space of $1.5 \mathrm{~m}$ between blocks of each replication (three plants) was used to avoid fruit harvest confusions. Soil preparation, fertigation, plant protection, and other growing practices were those commonly used for melon cultivation in Mediterranean conditions (Fernández-Trujillo et al., 2005, 2007; Eduardo et al., 2007). Rows were dripirrigated using two emitters per plant. The plot was surrounded by a border line of cultivar Nicolás.

The field was divided in eight blocks containing at least one three-plant replication for each NIL (separated by $1.5 \mathrm{~m}$ between them or in relation to the border line), two for cultivar PS, and one or two for the reference cultivars (SC, Fado or Védrantais) in a completely randomized design within the block.

The last block contained only two replications of three NILs (5M2, $5 \mathrm{M} 9,5 \mathrm{M} 10)$ and six replications of cultivar PS. For cultivars SC and Fado, replications consisted of one single plant, though, in total, eleven or eight replicates, respectively, were planted in the field. The experimental design consisted of three plants per replication, $\mathrm{n}=9$ (for NILs 5M2, 5M9, and 5M10), $\mathrm{n}=20$ (for the parental line PS), and $n$ $=7$ for eight NILs - SC3-5 and 5M3 to $5 \mathrm{M} 8$ - and cultivar Nicolás).

The different number of replications for PS and the NILs was mandatory to use Dunnett contrast in order to establish differences between PS and the NILs. The nine replicates in some NILs were required for other parallel experiments and also to avoid possible plants death, taking into account their high susceptibility to decay due to the climacteric behavior (Eduardo et al., 2007). Other details of the experiment have been previously reported (Fernández-Trujillo et al., 2005).

The harvest period started on June 20 and ended on July 19, 2005, with fourteen harvests in total. The harvest indicators, which varied depending on the physiological behavior and cultivar, were: growth period, fruit size, skin waxing aspect, loss of skin trichomes, development of abscission layer, yellow ring or scar at the peduncle ( $1 / 2$ to full slip), death of first leaf beside peduncle, fruit compactness, ground spot skin color, netting aspect, characteristic skin color or aroma for the climacteric NILs or reference cultivars, and soluble solids accumulation of samples obtained during the two weeks that preceded harvest (levels should be around 12 to $14^{\circ}$ Brix for PS and cultivar Nicolás, and a minimum of $10^{\circ}$ Brix).

To avoid mechanical damages to the very delicate skin, fruits of cultivar SC were covered for transportation to the laboratory with soft freshly harvested weeds. 
Disorders inspection and evaluation - in order to study storage disorders and decay, at least four fruits per replicate were weighed and randomly stored in boxes at $8 \pm 0.6^{\circ} \mathrm{C}$ and $87 \pm 2 \% \mathrm{RH}$ for 30 days (except for cultivars Fado and Védrantais, which were only stored for 20 and 25 days, respectively). Fruits were covered with plastic liner (Plásticos del Segura, Murcia, Spain) one day after harvest to avoid water condensation.

Preharvest losses were examined in 153 fruits that were discarded during the three-week harvest of the NILs and reference cultivars. Digital pictures for every single fruit were obtained and the disorders and rots were identified in the laboratory, according to conventional methodology (Barnett \& Hunter, 1999; Martínez \& Fernández-Trujillo, 2007). Postharvest disorders were examined according to Fernández-Trujillo et al. (2007).

The uncommon disorders searched for were necrosis of the placental tissue, warted skin, net or stylar-end cracking, hollow flesh disorder (HFD), and slight sunburn symptoms. Healed stylar-end growth cracks (stylar-end cracking or healed split, basal healed cracking) were visually evaluated on a 0 to 4 visual scale, corresponding to none to very slight, slight, moderate, and severe symptoms (the latter two were usually associated with decay, although some hyphae of Cladosporium sp. and Fusarium sp. were only found under light microscopy, including all the very slight scales).

Data were transformed into a cracking index on a 0 to 100 scale. In order to discern the limits of stylar-end hardness that indicated over-ripening symptoms, this trait was measured in a separate experiment using five fruits per line at $21^{\circ} \mathrm{C}$. For hardness measurement, a $2 \mathrm{kN}$ cell setup with a double scale (only the 0 to $200 \mathrm{~N}$ scale was used using a 1/10 of the total graphic scale), was mounted on a textural machine (Ibertest Daganzo de Arriba, Madrid, Spain) with two deformation plates (one static). Hardness was calculated in $\mathrm{N}$ $\mathrm{mm}^{-1}$ by dividing the maximum force to obtain $2 \mathrm{~mm}$ deformation in whole melons, using $15 \mathrm{~mm} \mathrm{~min}^{-1}$ compression speeds and $1 \mathrm{~N}$ preload (FernándezTrujillo et al., 2005). Symptoms of fruit stylar-end softening in a four-range scale (severe, moderate, slight and very slight) were evaluated by hand and categories were preliminarily accommodated to instrumental measurements.

Statistical analysis - when needed, data were transformed into their respective arcsin to fit normal distribution before being subjected to analysis of variance using JMP 5.1.2 (SAS Institute Inc., Cary, NC, USA). To study the effect of the cultivar SC introgressions, mean NIL values were compared with the control genotype PS by the Dunnet contrast at $\mathrm{p} \leq 0.05$ (Eduardo et al., 2007). If the PS was completely free from the disorder, no statistical analysis was performed. To study differences between cultigens SC3-5, PS, SC, Fado, Nicolás, and Védrantais, data were subjected to analysis of variance and the significance among cultigen differences were assessed using the Tukey test, at $\mathrm{p} \leq 0.05$.

\section{RESULTS AND DISCUSSION}

Preharvest damaged fruit evaluation was conducted with fruit discarded in the field $(70 \%)$ or in the laboratory (30\%). The main preharvest losses (no additives) were due to slight to severe fruit cracking (seen in $71 \%$ of lost fruits), over-ripening (seen in 18\%), skin sunburn (seen in 11\%), bacterial soft rot (seen in 16\%), and birds and rodent attacks, natural dehiscence in the field (climacteric NILs were dehiscent) and fruit deformation (seen in $2 \%$ ).

Regarding parental lines preharvest losses, Piel de Sapo (PS) fruits were free from over-ripening symptoms, cracking, and less than 5\% fruit showed slight sunburn at harvest (data not shown), while Shongwan Charmi (SC) fruits did not crack but showed deep netting that usually formed skin scar while still attached to the plant. SC was also very sensitive to sunburn as its susceptibility to different diseases, fruit deformation, skin bruises, and damage frequently resulted in unmarketable fruit. To avoid this problem, well developed SC fruits were partly covered with fresh weeds in the field.

Preharvest losses in reference cultivars were caused by moderate to severe cracking. This problem was particularly noticeable in cultivar Védrantais melons (Figure 1A), representing $21 \%$ of the total losses in the field, 3.6 times more than what was observed in PS, and 6.4 fold the average losses of climacteric NILs.

The initial cracking in cultivar Védrantais developed sometimes already 1-2 hours after harvesting and transporting to laboratory (about 3\% of the fruits of this cultivar). Cracking was also a problem in $14 \%$ of fruits of cultivar Fado. In the field, 5M2 showed a similar cracking level as PS, particularly at the beginning of the season (Figure 1B). Melons from cultivar Vedrantais, whose skin is more sensitive to environmental factors or insect attacks compared to NILs or PS, frequently developed a warted skin that resembled the scarring commercially defined in netted melons (Figure 1C).

In the F1 hybrid non-climacteric cultivar Nicolás, some melons showed a slight aroma, typical of climacteric melon NILs, as observed by human nose (Figure 1D). This aroma was not detectable in the typical non-climacteric fruits obtained from cultivar Nicolás and was concomitant with partial skin degreening, leading to fruit with shorter shelf-life.

Preharvest losses in the NILs included moderate to severe sunburn symptoms in the fruit discarded in the field, particularly in climacteric NILs 5M4, 5M5, 5M9, 5M10 (Figure 1D; data not shown). Preharvest sunburn led to internal rind necrosis and the flesh close to the sunburn area was more prone to suffer cavities (data not shown).

Sunburn was the consequence of fruit exposure to the sun due to reduced foliar coverage provoked by aphid attack (Aphis gossypii Glover) and powdery mildew [Sphaerotheca fuliginea (Schlecht ex Fr.) Poll.], which affected mainly NILs and not the PS. The slight reduction of foliar coverage as a result of leaf injuries in most of plants before fruit set (Figure 2A \& 2B) also contributed to sunburn. Leaf injury was 


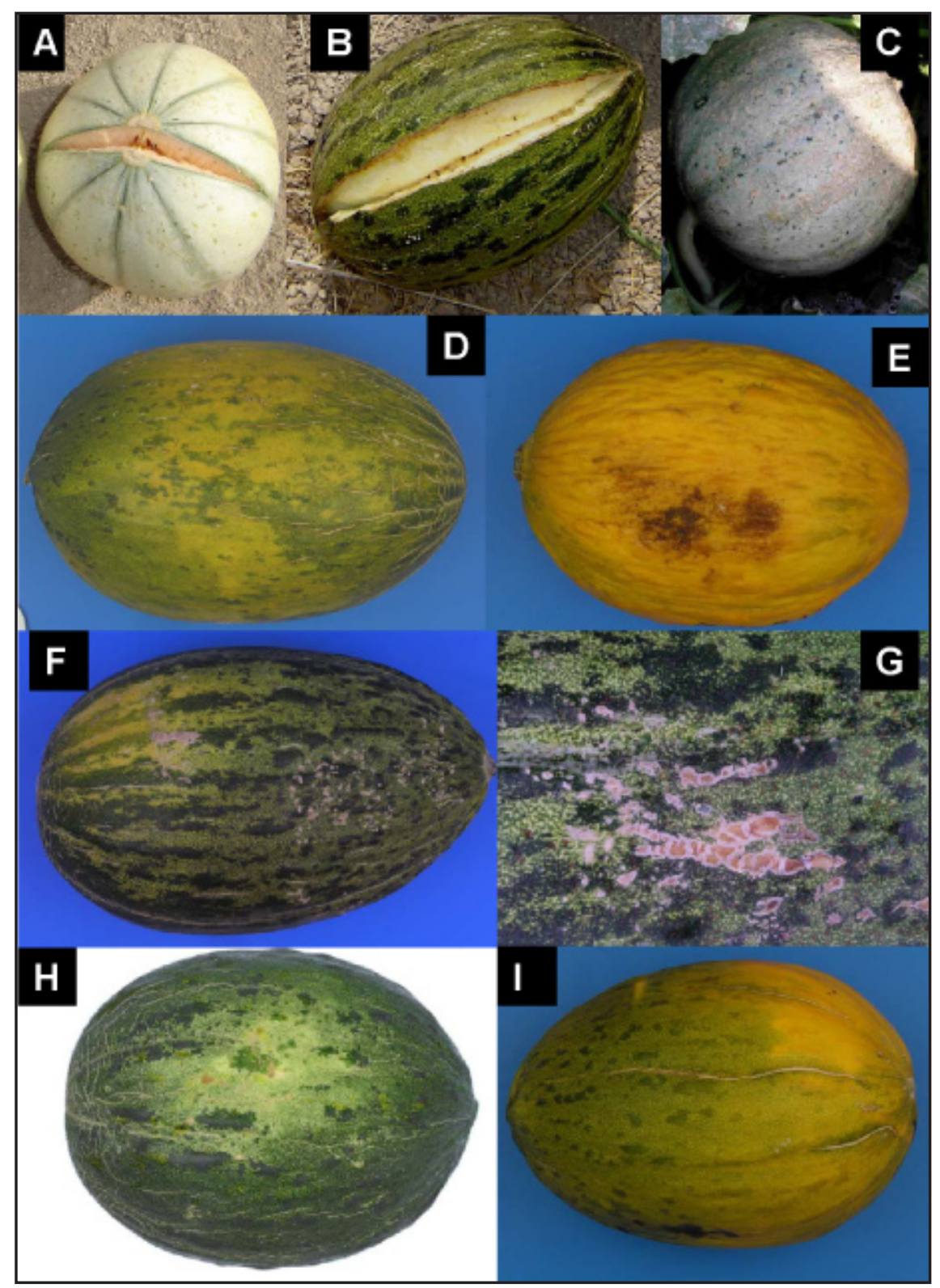

Figure 1. Skin and flesh disorders and decay at harvest in fruits of melon near-isogenic lines (NILs) and reference cultivars (alterações fisiológicas e podridões em frutos de melão de linhas quase-isogênicas e cultivares testemunhas); A: Whole fruit cracking Cantaloupensis Group, Naud, cultivar Védrantais (rachadura completa em frutos do grupo Cantaloupensis, Naud e cultivar Védrantais); B: Whole fruit cracking in the susceptible NIL 5M2 (rachadura completa em frutos da linha quase-isogênica suscetível 5M2); C: Warted skin (similar to scarring) in $C$. melo var. cantalupensis, Naud, cultivar Védrantais (casca verrugosa, semelhante a cicatrizes, in C. melo var. cantalupensis, Naud, cultivar Védrantais); D: Sunburn after harvest in NIL 5M5 (queima do sol após colheita em NIL 5M5); E: Abnormal skin yellowing in the cultivar Nicolás at harvest (amarelecimento anormal da casca na cultivar Nicolás na colheita); F, G: Warted skin in the parental Piel de Sapo (PS) line and detail (casca verrugosa e detalhe na linha parental Piel de Sapo (PS)); H: Typical blue-green color in the ground skin area of NIL $5 \mathrm{M} 7$, with a typical late harvest (coloração típica azul-esverdeada na área da casca sobre o solo de NIL 5M7, com colheita tipicamente atrasada); I: Deep furrow in netting of NIL 5M8 (ornamentação profundamente sulcada no NIL 5M8). Cartagena, UPCT, 2008.

probably due to wind injury causing leaf bruising. Other environmental factors alone or in combination may also cause leaf bruising, such as rain, temperature
(Blancard et al., 1996).

Bacterial soft rot caused by Erwinia carotovora subsp. carotovora (Jones) was found in the peduncle of $16 \%$ of field discarded over-ripe fruit (about 1 to 4 fruits per NIL or cultivar, except in NILs 5M6, 5M7, and 5M9, in which the bacteria did not develop). Fusarium rot, caused by Fusarium sp. Link, was negligible in the field (only one fruit in 5M4).

Fruit deformation and pear shaped fruit, which had small size, were more frequent in NILs 5M4, 5M8, 5M9, and 5M10 (data not shown). Fruit deformation or internal cavities in pearshaped fruits have been attributed to poor pollination at certain moments of the season (Blancard et al., 1996). Other uncommon skin and flesh disorders at harvest or after storage at $8^{\circ} \mathrm{C}$ were observed.

The scarring or warted skin was recorded at harvest but particularly after storage at $8^{\circ} \mathrm{C}$, and also in some cultivar Nicolás fruits after subsequent storage trials at $21^{\circ} \mathrm{C}$ (data not shown). The warted skin disorders slightly spoilt the skin appearance. The disorder was uncommon and not critical for PS or the nonclimacteric NIL 5M7 (Figures $1 \mathrm{~F}$ and $\mathrm{G}$ ), or in other NILs such as 5M3.

The warted skin disorder resembled cucurbit scab (Zitter, 1986). In previous studies, fruit warted skin has been associated with insects or environmental factors such as the sudden RH fluctuations in the field during the autumn or high irrigation levels (San Bautista et al., 2004). Therefore, development of warted skin in refrigerated rooms is very most likely.

The warted skin disorder resembles scab but is not provoked by Cladosporium cucumerinum Ellis and Arth., which is responsible for scab (Zitter, 1986; Vegh1Inra, 2005). As we did not observe the typical development symptoms of the fungus (such as its special leaf or stem symptoms, typical protuberant spots, or favorable low temperatures and high $\mathrm{RH}$ conditions in the field) we assume that the Cladosporium sp. observed in our experiment should be $C$. herbarum which only grows during storage or senescence leaves. 


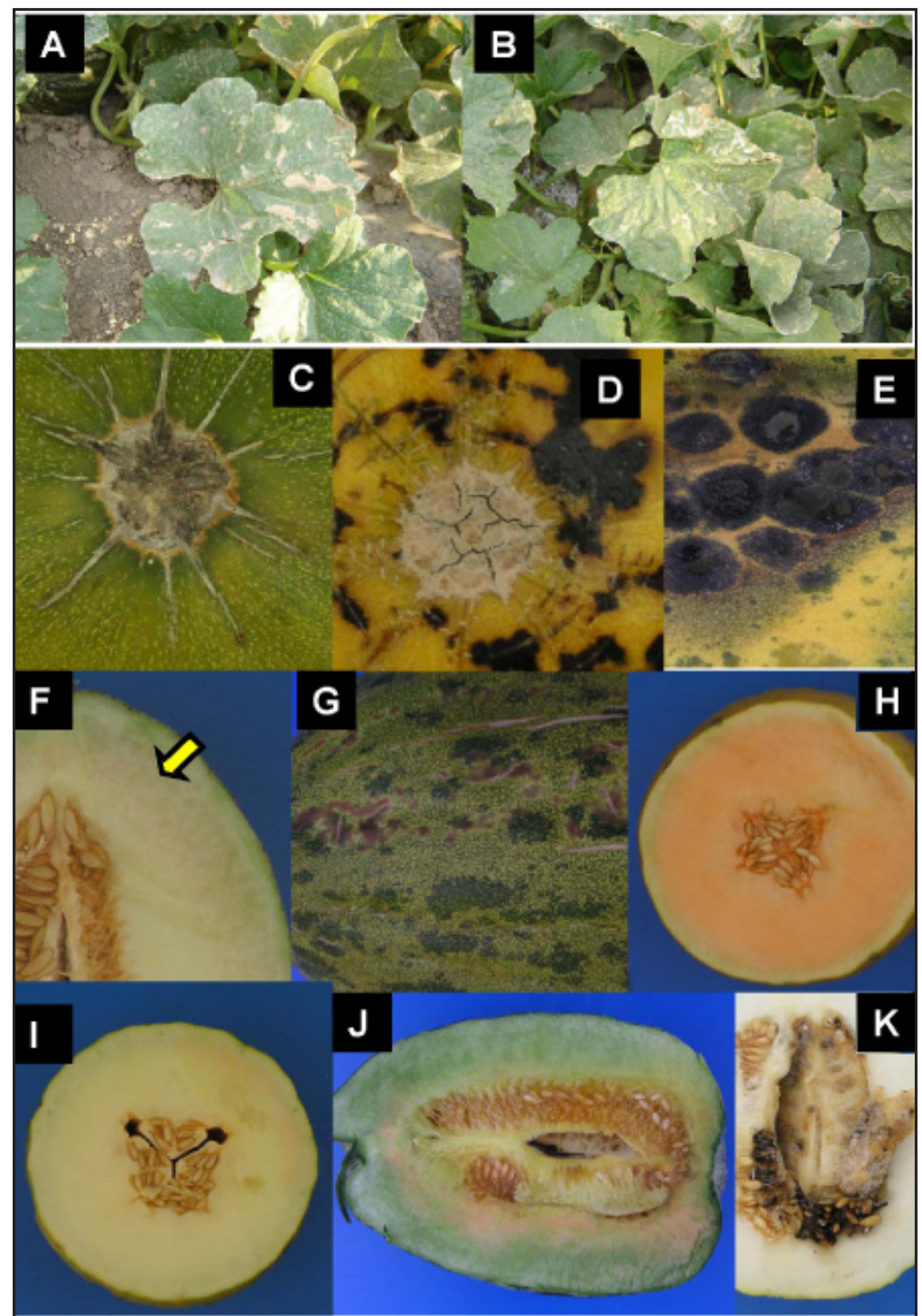

Figure 2. Preharvest leaf injuries and skin and flesh disorders and decay after 30 days at $8^{\circ} \mathrm{C}$ in fruit of several melon near-isogenic lines (NILs) and reference cultivars (injúrias foliares e alterações e podridão na casca e polpa de frutos armazenados por 30 dias a $8^{\circ} \mathrm{C} \mathrm{em}$ linhas quase-isogênicas (LQI) e cultivares referências de melão); A: Wind injury in leaves of melon parental line (injúrias causadas pelo vento em folhas da linha parental de melão); B: Wind injury in leaves of NIL SC3-5 (injúrias causadas pelo vento na LQI SC3-5); C: Moderate stylar-end cracking in NIL 5M4 surrounded by scald (rachadura moderada na região pistilar na LQI 5M4, circundada por escaldadura); D: Stylar-end cracking in NIL 5M6 affected by Cladosporium rot (rachadura da região pistilar na LQI 5M6 afetada pela podridão de Cladospório); E: Cladosporium rot developing on a sunburn area plus skin scald in NIL 5M5 (podridão de Cladospório desenvolvida em area com queimadura de sol e escaldadura da casca na LQI 5M5); F: Very slight flesh browning of unknown origin in NIL 5M3 (leve escurecimento da polpa, de origem desconhecida, na LQI 5M3); G: External skin symptoms associated with slight internal flesh browning in NIL 5M3 (sintomas externos na casca associados ao leve escurecimento da polpa na LQI 5M3); H: Orange flesh in partly over-mature fruit of NIL 5M4 (polpa alaranjada em frutos parcialmente passados da LQI 5M4); I: Yellow flesh in partly over-mature fruits of NIL 5M10 (polpa amarela em frutos parcialmente passados da LQI 5M10). J: Typical incidence of necrosis of the placental tissue in the exotic Korean accession Shongwan Charmi, PI 161375, or SC, Conomon Group, also detected at harvest (incidência típica de necrose no tecido placentário no acesso coreano exótico Shongwan Charmi, PI 161375, ou SC, grupo Conomon, também detectado na colheita); K: Necrosis of the placental tissue colonized by Cladosporium rot in NIL 5M10 (necrose do tecido placentário colonizado por podridão de Cladospório na LQI 5M10). Cartagena, UPCT, 2008.
The NIL 5M7 showed difficulty in completing the ripening process, which was delayed by 7-10 days compared to the climacteric NILs. This was revealed by the presence of blue greenish areas in the area of the skin which was in contact with the soil (in less than $4 \%$ fruit), indicating partial immaturity on this side of the fruit and particularly in the area contacted with the soil (Figure $1 \mathrm{H})$. These symptoms were probably associated with a poor leaf status, and the difficulty experienced by the plant to obtain resources for the fruit.

Deep furrow netting inherited from $\mathrm{SC}$ in some NILs was also detected (Figure 1I), and also symptoms of healed split and stylar-end cracking (alone or with visually Cladosporium rot) in the climacteric NILs (Figures 2C and D). If fruit with moderate sunburn were stored, they usually developed Cladosporium rot (Figure 2E).

Some fruits also developed a diffuse light brown pulp (Figure 2F), rarely accompanied by external symptoms (Figure 2G), while other fruits developed a typical orange flesh color, characteristic of senescence and inherited from SC (particularly in NIL 5M4, Figure 2H), or yellow flesh typical from PS in 5M10 (Figure 2I).

Placental necrosis was an internal disorder detected at harvest and also after storage at $8^{\circ} \mathrm{C}$. Necrosis was detected in NIL 5M3 (7\% fruit with slight necrosis after storage) and 5M10 (6\% fruit at harvest and $2 \%$ after storage) (Tables 1 and 2; Figures 2J and K), which we assume was inherited from SC (17\% fruit affected at harvest and 5\% after storage; Tables 1 and 2). This necrosis was previously reported in SC and in other NILs with a possible association with Cladosporium rot (Eduardo et al., 2007; Fernández-Trujillo et al., 2007), though this association was not always detected in recent seasons (data not shown).

It could be hypothesized that preharvest conditions can be associated with necrosis, and refrigerated storage promotes the colonization of the mentioned disorder by providing conditions suitable for saprophytic fungi. However, no symptoms of fungal growth or bacteria were detected in 


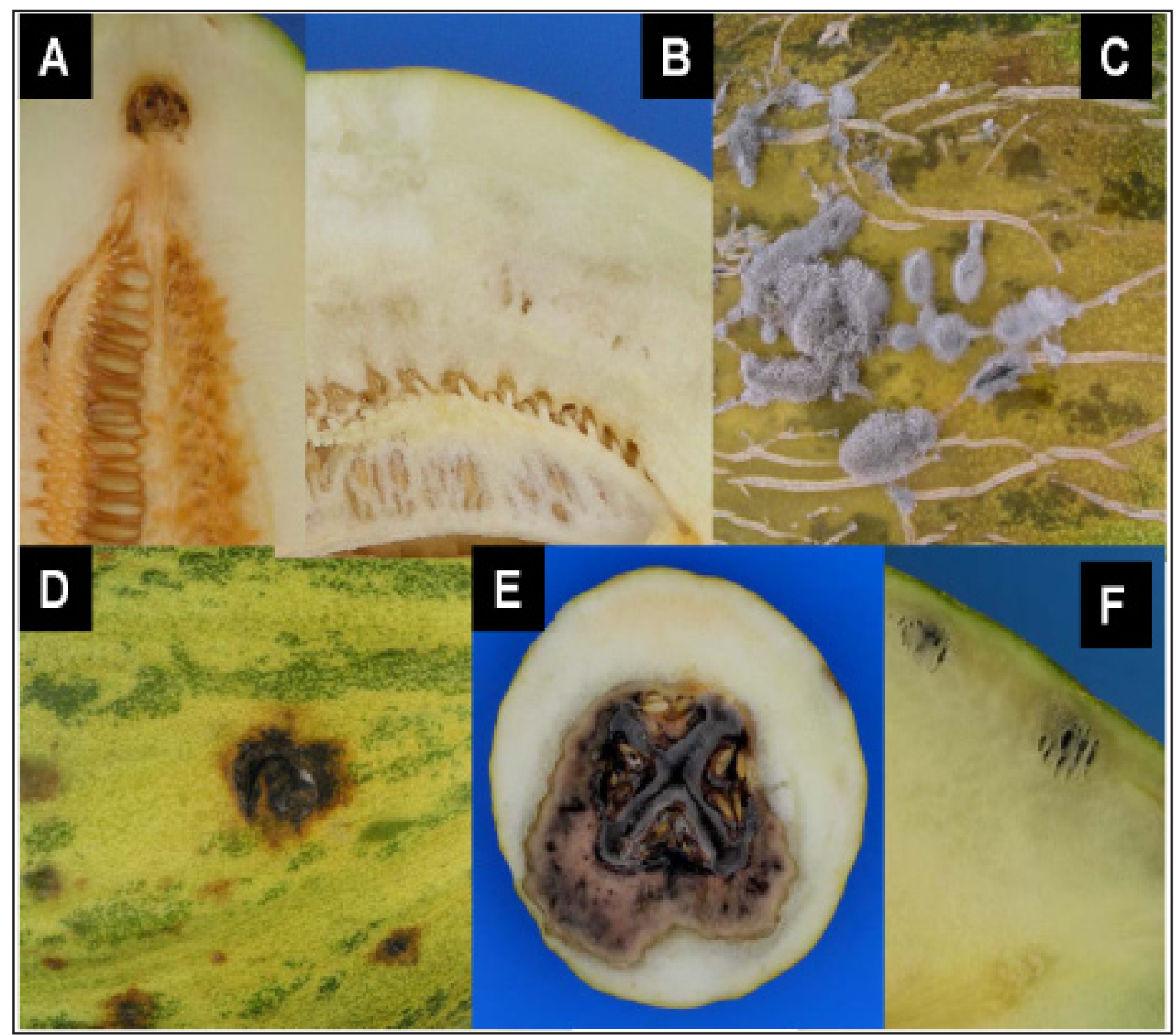

Figure 3. Skin and flesh disorders and decay in fruits of several near-isogenic lines (NIL) of melon and reference cultivars, after a 30-day storage period at $8^{\circ} \mathrm{C}$ (desordens e podridões da casca e polpa de frutos de várias linhagens quase isogênicas (LQI) e cultivares testemunhas de melão, após um período de 30 dias de armazenamento a $8^{\circ} \mathrm{C}$ ); A: Detail of internal corky flesh in NIL 5M4, probably as a result of Alternaria rot (detalhe da polpa com textura de cortiça na LQI 5M4, provavelmente como resultado de podridão de Alternária); B: Hollow flesh disorder (HFD) in NIL 5M9 (polpa esponjosa na LQI 5M9); C: Grey mould rot in F1 hybrid of melon (Inodorus Group), cultivar Nicolás (mofo-cinzento no híbrido F1 de melão (Grupo Inodoro), cultivar Nicolás); D: Phytium phytophtora on pitting in NIL SC3-5 (Phytium phytophtora causando lesões na LQI SC3-5); E: Internal Cladosporium rot in NIL 5M8 (podridão de Cladospório interna na LQI 5M8). F: Holes provoked by internal Cladosporium rot in NIL 5M5 (podridão de Cladospório interna na LQI 5M5). Cartagena, UPCT, 2008.

brown cells of the placental tissue and tissues surrounding (data not shown). The presence of the disorder in NIL $5 \mathrm{M} 10$ may indicate the presence of a QTL for necrosis not previously reported for SC3-5ab (FernándezTrujillo et al., 2007).

Other flesh disorders rarely found at harvest (Table 1) were corky dry texture with brown areas (Figure 3A) or the hollow flesh disorder in NILs 5M8,
5M9 and 5M10 (Figure 3B). The exact location of these disorders affecting small areas depended on the fruit section excised. The incidence of hollow flesh disorder in other NILs such as SC3-5ab at harvest or after storage (less than $10 \%$ fruits affected) suggests a higher presence of HFD in advanced stages of maturity or senescent fruit because it was only present in climacteric NILs (Fernández-Trujillo et al., 2007). In cucumber, a similar disorder to HFD is pillowy fruit disorder (PFD). PFD increases as a result of water stress under inadequate postharvest procedures (absence of hydrocooling after harvest or abuse of storage at high temperatures) that promote ripening and softening (Staub \& Navazio, 1993; Navazio \& Staub, 1994; Serce et al., 1999;).

Stylar-end cracking after storage did not affect PS, but it mostly affected cultivar Fado (85\% fruit) and 1-3\% 
Table 1. Fruit internal disorders at harvest in near-isogenic lines ( $\mathrm{SC} 3-5,5 \mathrm{Mx}, \mathrm{x}=2$ to 10$)$ of melon, their parental lines, and reference cultivars (desordens internas em frutos na colheita em linhagens quase-isogênicas ( $\mathrm{SC} 3-5,5 \mathrm{Mx}, \mathrm{x}=2$ a 10) de melão, suas linhagens parentais e cultivares testemunhas). Cartagena, UPCT, 2008.

\begin{tabular}{|c|c|c|c|}
\hline Pedigree & Replication & $\begin{array}{c}\text { Total number of } \\
\text { fruits }\end{array}$ & $\begin{array}{l}\text { Internal flesh } \\
\text { disorders (\%) }\end{array}$ \\
\hline $\mathrm{SC} 3-5^{1}$ & 7 & 18 & 0 \\
\hline $5 \mathrm{M} 2$ & 9 & 16 & 0 \\
\hline $5 \mathrm{M} 3$ & 7 & 14 & 14 \\
\hline $5 \mathrm{M} 4$ & 7 & 15 & 7 \\
\hline $5 \mathrm{M} 5$ & 7 & 14 & 21 \\
\hline $5 \mathrm{M} 6$ & 7 & 4 & 0 \\
\hline $5 \mathrm{M} 7$ & 7 & 14 & 0 \\
\hline $5 \mathrm{M} 8$ & 7 & 14 & 0 \\
\hline $5 \mathrm{M} 9$ & 9 & 21 & 6 \\
\hline $5 \mathrm{M} 10$ & 9 & 18 & 6 \\
\hline $\mathrm{PS}^{2}$ & 20 & 41 & $3 \pm 0.1^{6}$ \\
\hline \multicolumn{3}{|c|}{ ANOVA PS vs. NILs (Dunnett, $p<0.05$ ) } & ns \\
\hline $\mathrm{SC}^{1}$ & 11 & 23 & 17 \\
\hline Fado $^{3}$ & 7 & 13 & 0 \\
\hline Nicolás ${ }^{4}$ & 6 & 13 & 0 \\
\hline Védrantais $^{5}$ & 8 & 17 & 2 \\
\hline \multicolumn{3}{|c|}{ ANOVA SC3-5, PS and cultivars (Tukey, $p<0.05$ ) } & ns \\
\hline \multicolumn{4}{|c|}{$\begin{array}{l}{ }^{1} \text { Korean accession Shongwan Charmi (PI 161375), Conomon Group (acesso coreano Shong- } \\
\text { wan Charmi (PI 161375), grupo Conomon); }{ }^{2} \mathrm{PS} \text { = Cultivar Piel de Sapo parental line (linha } \\
\text { parental da cultivar Piel de Sapo); }{ }^{3} \text { Cucumis reticulatus cultivar Fado, Galia type (Cucumis } \\
\text { reticulatus cultivar Fado, tipo Galia); }{ }^{4} \text { Cucumis melo cultivar Nicolas, commercial F1 hybrid, } \\
\text { Piel de Sapo type (Cucumis melo cultivar Nicolas, híbrido F1 comercial, Piel de Sapo); }{ }^{5} \text { C. } \\
\text { melo var. cantalupensis Naud, cultivar Védrantais (C. melo var. cantalupensis Naud, cultivar } \\
\text { Védrantais); }{ }^{6} \text { Means and standard deviation (média e desvio-padrão). }\end{array}$} \\
\hline
\end{tabular}

fruit of 5M2 or other climacteric NILs (Table 2). This level of cracking was in agreement with other results in Galia melons stored at ripening temperatures (Lima et al., 2004).

Védrantais melons were dehiscent, leading to a rapid stylar-end cracking when ripen in the field. Due to the softening at the fruit stylar-end, the hardness of this area was measured. Fruit hardness limits for severe, moderate, slight, and very slight symptoms of fruit stylar-end softening (in $\mathrm{N} \cdot \mathrm{mm}^{-1}$ ) were $<7,7-12,12-20$, and 20-35, respectively. Fruit with fruit stylarend hardness values above $35 \mathrm{~N} \cdot \mathrm{mm}^{-1}$ never showed fruit stylar-end cracking, nor showed over-ripening symptoms. Fruit stylar-end cracking developed at hardness values below $20 \mathrm{~N} \cdot \mathrm{mm}^{-1}$ (data not shown).

Stylar-end cracking was only observed (data not shown).

Uncommon rots detected after 30 days of storage at $8^{\circ} \mathrm{C}$ (absent or ranging from 2 to $5 \%$ in the NILs) sometimes showed higher levels in reference cultivars, but not in PS, and were as follows (Table 2; data not shown): grey mould rot caused by Botrytis sp. Pers. (detected after storage in NIL 5M10 and cultivars SC and Nicolás; Figure 3C); cottony leak, caused by Phytium sp. (on small pitted areas after storage in NIL SC3-5 and in PS; Figure 3D); bacterial soft rot located in NILs SC3-5, 5M4, and 5M9; Penicillium sp. Link. (in NIL 5M5 and cultivar SC, as a secondary fungi); Fusarium sp. (particularly on cultivar SC after three weeks of storage or more); and Acremonium sp. affecting the placental tissue (in NIL 5M10 and cultivar SC).

Internal Cladosporium rot covering the placental tissue (Figure 3E) or forming small internal cavities close to the skin (Figure 3F) was rarely detected. Internal Cladosporium rot affected the pulp tissue as a small cavity close to the epidermis (in a few fruit of NILs $5 \mathrm{M} 8$ or $5 \mathrm{M} 10$ ), and was usually concomitant with external observations of brown and soft skin. Sometimes it caused a slight decay mostly detected at the peduncle or in netted areas. This internal Cladosporium rot, associated or not with placental necrosis (Figure 3E), was externally undetectable except in advanced stage of development when it was revealed by a typical smell to soil.

Internal cavities with Cladosporium $\operatorname{rot}$ (Figure 3F) were probably associated with skin or peduncle lesions (due to sun radiation, sunburn, etc.) caused by a micro cracked epidermis during fruit development and storage. From this point of view, peduncle dehiscence, skin susceptibility to sunburn, etc., would modulate the onset of Cladosporium rot. In fact, our hypothesis is that Cladosporium sp. is probably unable to cause skin damages in melon because cannot metabolize it and so only would proliferate with difficulty in the pulp under microaerobic conditions.

Aerial hyphae can only proliferate when skin damages are evident. This is necessary to form the conidiosphores bearing conidia to spread the fungus. 
Table 2. Losses and physiological disorders in fruits of near-isogenic lines and other cultivars of melon, after a 30-day storage period at $8^{\circ} \mathrm{C}$, except for fruits of cultivars Fado and Védrantais, stored for 20 and 25 days, respectively (perdas e desordens fisiológicas em frutos de linhagens quase-isogênicas e outras cultivares de melão após um período de armazenamento de 30 dias a $8^{\circ} \mathrm{C}$, exceto para frutos das cultivares Fado e Védrantais, armazenados por 20 e 25 dias, respectivamente). Cartagena, UPCT, 2008.

\begin{tabular}{|c|c|c|c|c|c|c|c|c|c|c|c|c|c|c|c|c|}
\hline NIL or cultivar & SC3-5 & $5 \mathrm{M} 2$ & $5 \mathrm{M3}$ & $5 \mathrm{M} 4$ & $5 M 5$ & $5 M 6$ & $5 \mathrm{M} 7$ & $5 \mathrm{M8}$ & $5 M 9$ & $5 \mathrm{M10}$ & $\mathbf{P S}^{1}$ & $P^{2}$ & $\mathbf{S C}^{3}$ & Fado $^{4}$ & $\mathrm{Nic}^{5}$ & Ved $^{6}$ \\
\hline Replicates & 7 & 9 & 7 & 7 & 7 & 7 & 7 & 7 & 9 & 9 & 20 & - & 8 & 5 & 7 & 8 \\
\hline Fusarium rot (\%) & $2 \mathrm{a}$ & 0 & 0 & 0 & 1 & 2 & 0 & 0 & 0 & 0 & $0 \mathrm{a}$ & $\mathrm{ND}$ & $8 \mathrm{a}$ & $13 \mathrm{a}$ & $0 \mathrm{a}$ & $0 \mathrm{a}$ \\
\hline $\begin{array}{l}\text { Penicillium rot } \\
(\%)\end{array}$ & $0 \mathrm{a}$ & 0 & 0 & 0 & 2 & 0 & 0 & 0 & 2 & 4 & $0 \mathrm{a}$ & ND & $5 \mathrm{a}$ & $0 \mathrm{a}$ & $14 \mathrm{a}$ & 0a \\
\hline Botrytis $\operatorname{rot}(\%)$ & $0 \mathrm{a}$ & 0 & 0 & 0 & 0 & 0 & 0 & 0 & 1 & 3 & $0 \mathrm{a}$ & ND & $9 \mathrm{a}$ & $0 \mathrm{a}$ & $0 \mathrm{a}$ & $2 \mathrm{a}$ \\
\hline $\begin{array}{l}\text { Bacterial soft rot } \\
(\%)\end{array}$ & $2 \mathrm{a}$ & 0 & 0 & 1 & 0 & 0 & 0 & 0 & 1 & 0 & $0 \mathrm{a}$ & ND & $0 \mathrm{a}$ & $0 \mathrm{a}$ & $0 \mathrm{a}$ & 0a \\
\hline Net cracking (\%) & $1.6 \mathrm{a}$ & 8.2 & 3.9 & 2.1 & 0.0 & 0.0 & 2.0 & 6.7 & 0.0 & 1.9 & $4 \pm 4 a^{7}$ & NS & $0 \mathrm{~b}$ & $0 \mathrm{~b}$ & $0 b$ & $0 \mathrm{~b}$ \\
\hline $\begin{array}{l}\text { Skin wartness } \\
(\%)\end{array}$ & $0.0 \mathrm{a}$ & 2.3 & 0.0 & 0.0 & 0.0 & 0.0 & 3.3 & 0.0 & 0.0 & 0.0 & $1 \pm 1 \mathrm{a}^{7}$ & NS & $0 \mathrm{a}$ & $0 \mathrm{a}$ & $5 \mathrm{a}$ & $0 \mathrm{a}$ \\
\hline $\begin{array}{l}\text { Stylar-end crack- } \\
\text { ing }(\%)\end{array}$ & $3.4 \mathrm{a}$ & 2.5 & 0 & 2.1 & 0 & 0 & 0 & 0 & 3.4 & 1.1 & $0 \mathrm{a}$ & ND & $0 \mathrm{a}$ & $85 \mathrm{~b}$ & $0 \mathrm{a}$ & $4 \mathrm{a}$ \\
\hline $\begin{array}{l}\text { Necrosis of the } \\
\text { placental tissue } \\
\text { index (\%) " }\end{array}$ & $0 \mathrm{a}$ & 0 & 0.9 & 0 & 0 & 0 & 0 & 0 & 0 & 0.4 & $0 \mathrm{a}$ & $\mathrm{ND}$ & $5 b$ & $0 \mathrm{a}$ & $0 \mathrm{a}$ & $0 \mathrm{a}$ \\
\hline
\end{tabular}

Means followed by the same letter in the column did not differ significantly from each other, Tukey Test, $\mathrm{p}<0.05$ (médias seguidas de mesma letra na coluna não diferem significativamente entre si, teste de Tukey, $\mathrm{p}<0.05$ ); $\mathrm{ND}=$ not determined because PS was free from the disorder or rot (não determinado porque PS não apresentou a desordem ou podridão); ${ }^{1} \mathrm{PS}=$ cultivar Piel de Sapo parental line (linhagem parental da cultivar Piel de Sapo); ${ }^{2} P=$ probability for the Dunnett test (probabilidade de acordo com o teste de Dunnet); ${ }^{3} \mathrm{SC}=\mathrm{Korean}$ accession Shongwan Charmi (PI 161375), Conomon Group (acesso coreano Shongwan Charmi (PI 161375), grupo Conomon); ${ }^{4}$ Cucumis reticulatus cultivar Fado, Galia type (Cucumis reticulatus cultivar Fado, tipo Galia); ${ }^{5}$ Cucumis melo cultivar Nicolas, commercial F1 hybrid, Piel de Sapo type (Cucumis melo cultivar Nicolas, híbrido F1 comercial); ${ }^{6} C$. melo var. cantalupensis Naud, cultivar Védrantais (C. melo var. cantalupensis Naud, cultivar Védrantais); ${ }^{7}$ Means and standard deviation (média e desvio-padrão).

Most of the microorganisms reported in postharvest are common in Cucurbitaceae or other fruit species around the world, and cause grey mould rot or Cladosporium rot (Martínez \& Fernández-Trujillo, 2007; Snowdon, 1991). Alternaria sp., Rhizopus sp., Fusarium sp., Stemphylium sp., Trichothecium sp., Penicillium sp., Aspergillus sp., Epicoccum sp., Erwinia, and Pseudomonas bacteria damages have also been reported in previous studies (Ceponis et al., 1986; Snowdon, 1991; Chen et al., 2001; Morris et al., 2001; Albuquerque et al., 2005). This is while, internal Cladosporium rot is not common and only Alternaria and Cladosporium rot are observed in cold stored Piel de Sapo type and Fusarium rot and Mucor rot in other C. melo Inodorus Group (Ceponis et al., 1986; Snowdon, 1991; Yang et al., 2003; Albuquerque et al., 2005).

The importance of rare microorganisms in melons such as Penicillium expansum, in spite of being restricted to the fruit surface, resides in potentially increasing fruit susceptibility to later infection by pathogenic microorganisms (Richards \& Beuchat, 2005).

The uncommon physiological disorders and melon defects reported herein may also be attributed partially to the differences in genetic background and the different behavior of the progenitors and/or the ethylene insensitivity conferred by the recessive allelic forms of SC (PÉRIN et al., 2002). NILs were efficient at revealing dissect complex traits, including disorders and decay (Eduardo et al., 2007; FernándezTrujillo et al., 2007). However, some of them such as hollow flesh were rarely found in the main NIL collection and were not detected in PS. Many of the defects reported herein may be of importance in some degree from a processing and appearance point of view, but clearly introduced greater variability in fruit internal quality. However, some of the defects may be an indication of a deteriorated fruit quality that renders the fruit useless for further processing (e.g. fresh-cut fruit, cremogenates, etc.) (Cantwell \& Portella, 1998). These minor disorders can be incorporated in future "expert systems" for the automatic diagnosis of melon disorders (Latin et al., 1990). New NILs for fine mapping are required in order to confirm the results of every disorder.

In summary, preharvest losses were mainly due to fruit cracking and, to a lesser extent, bacterial soft rot, over-ripening, and skin sunburn. The NILs with climacteric behaviour were more susceptible to over-ripening, skin sunburn, hollow flesh disorder and stylar-end cracking, accompanied by softening as measured by hardness values below $20 \mathrm{~N} \cdot \mathrm{mm}^{-1}$ in this zone. Other uncommon disorders such as warted skin, flesh discoloration to light brown or translucent areas were not associated with the climacteric pattern.

Necrosis of the placental tissue in two NILs and deep furrow netting were inherited from the Korean accession SC but were unrelated with climacteric 
behavior. Some uncommon decays such as internal Cladosporium rot, seems to be associated with skin deterioration. The incidence of the uncommon disorders or the rots described was too low to confirm the influence of a possible genetic component in their development.

\section{ACKNOWLEDGEMENTS}

This work was funded by grants 05676/PI/07 and 00620/PI/04 (Fundación Séneca de la Región de Murcia), BIO-AGR06/02-0011 (Consejería de Educación y Cultura de la Región de Murcia), AGL2003-09175-C02-01 and AGL2003-09175-C02-02 from the Spanish Ministry of Education and Science and Fondo Europeo de Desarrollo Regional (FEDER, European Union).

J. Obando and E. Moreno were supported by fellowships from MAEAECI (Spanish Ministry of Foreign Affairs) and AGAUR (Generalitat de Cataluña) respectively.

We thank CIFEA team (Consejería de Agricultura, Región de Murcia) for the field and crop management. Thanks to Semillas Fitó S.A. (Barcelona, Spain) for providing the seeds of the parental line of cultivar Piel de Sapo and the commercial Galia type; to Plásticos del Segura S.L. (Murcia) for providing the plastic liners; and to Syngenta Seeds (Torre Pacheco, Murcia) for providing the seeds of cultivar Nicolás.

Cultivar Védrantais seeds were a gift of Michel Pitrat (INRA, Montfavet, France). We are indebted to Claudia Miranda and Mohammad Kazem Souri for technical assistance.

\section{REFERENCES}

ABDEL-AL ZE. 1975. The effects of irrigation frequency and cultivars on premature cracking and blossom-end rot of watermelon fruits grown in the Sudan. Acta Horticulturae 49: 185-192.

ALBUQUERQUE B; LIDÓN F; GOMES MJ. 2005. Comparison between different anti-fungal treatments in Tendral melons decay. Electronic Journal of Environmental, Agricultural and Food Chemistry 4(5). Available at http:// ejeafche.uvigo.es/4(5)2005/006452006F.htm Accessed in February 1, 2007.

BARNETT HL; HUNTER BB. 1999. Illustrated genera of imperfect fungi. Minnesota: The American Phytopathological Society, 218p.

BLANCARD D; LECOQ H; PITRAT M. 1996. Enfermedades de las cucurbitáceas. Madrid: Mundi-Prensa libros SA, 301p.

CANTWELL M; PORTELLA S. 1998. The importance of raw material quality for freshcut products: The impact of melon defect as an example. Perishables Handling Quarterly, 96: 2-3.

CEPONIS MJ; CAPPELLINI RA; LIGHTNER GW. 1986. Disorders in muskmelon shipments to the New York market, 1972-1984. Plant Disease 70: 605-607.

CHEN N; AN L; MA K. 2001. The postharvest handling system for melon in northwestern China- status, problems, and prospects. In: O'HARE T; BAGSHAW J; LI W; JOHNSON $\mathrm{G}$ (eds.). Postharvest handling of fresh vegetables. Canberra: Australian center for international agricultural research. ACIAR Proceedings 105, p. 38-43.

EDUARDO I; ARÚS P; MONFORTE AJ. 2005. Development of a genomic library of nearisogenic lines (NILs) in melon (Cucumis melo L.) from the exotic accession PI161375. Theoretical and Applied Genetics 112: 139. 148.

EDUARDO I; ARÚS P; MONFORTE AJ; OBANDO J; FERNÁNDEZ-TRUJILLO JP; MARTÍNEZ JA; ALARCÓN AL; ÁLVAREZ JM; VAN DER KNAAP E. 2007. Estimating the genetic architecture of fruit quality traits in melon (Cucumis melo L.) using a genomic library of near-isogenic lines. Journal of the American Society for Horticultural Science 132: 80-89.

FERNÁNDEZ-TRUJILLO JP; OBANDO J; MARTÍNEZ JA; ALARCÓN AL; EDUARDO I; ARÚS P; MONFORTE AJ. 2005. Quality management of experiments with a collection of near-isogenic lines of melon. In: ATIENZA J; RABASSEDA J (eds.): THIRD VIRTUAL IBEROAMERICAN CONGRESS LABORATORY QUALITYMANAGEMENT "III IBEROLAB". Proceedings. Madrid: Ministerio de Agricultura, Pesca y Alimentación, p. 149-158 (CD-ROM).

FERNÁNDEZ-TRUJILLO JP; OBANDO J; MARTÍNEZ JA; ALARCÓN AL; EDUARDO I; ARÚS P; MONFORTE AJ. 2007. Mapping fruit susceptibility to postharvest physiological disorders and decay using a collection of near-isogenic lines of melon. Journal of the American Society for Horticultural Science 132: 739-748.

FERNÁNDEZ-TRUJILLO JP; OBANDOULLOA JM; MARTÍNEZ JA; MORENO E; GARCÍA-MAS J; MONFORTE AJ. 2008. Climacteric or non-climacteric behavior in melon fruit 2. Linking climacteric pattern and main postharvest disorders and decay in a set of near-isogenic lines. Postharvest Biology and Technology 50: 125-134.

FLORES FB; ROMOJARO F; LATCHÉA; PECH JC; MARTÍNEZ-MADRID MC. 2007. Assay of a potential post-harvest handling procedure for cantaloupe Charentais melon fruit with inhibited ethylene production. Journal of the Science of Food and Agriculture 87:
2034-2039

LATIN RX; MILES GE; RETTINGER JC; MITCHELL JR. 1990. An expert system for diagnosing muskmelon disorders. Plant Disease 74: 83-87.

LIMA MAC; ALVES RE; BISCEGLI CI; FILGUEIRAS HAC; COCOZZA FM. 2004. Postharvest storage of Galia 'Solar King' muskmelon treated with 1-methylcyclopropene. Horticultura Brasileira 22: 121-126.

MARTÍNEZ JA; FERNÁNDEZ-TRUJILLO JP. 2007. Necrotrophic fungi associated with epidermal microcracking caused by chilling injury in pickling cucumber fruit. Pesquisa Agropecuária Brasileira 42: 593-598.

MORALES M; ORJEDA G; NIETO C; VAN LEEUWEN H; MONFORT A; CHARPENTIER M; CABOCHE M; ARÚS P; PUIGDOMENECH P; ARANDA MA; DOGIMONT C; BENDAHMANE A; GARCÍA-MAS J. 2005. A physical map covering the nsv locus that confers resistance to melon necrotic spot virus in melon (Cucumis melo L). Theoretical and Applied Genetics, 111: 914-922.

MORENO E; OBANDO J; DOS-SANTOS N; FERNÁNDEZ-TRUJILLO JP; MONFORTE AJ; GARCÍA-MAS J. 2008. Candidate genes and QTLs for fruit ripening and softening in melon. Theoretical and Applied Genetics 116: 589-602.

MORRIS S; McCONCHIE R; MA K; WENHUA T. 2001. Postharvest handling of melons in Australia and China. In: O'HARE T; BAGSHAW J; LI W; JOHNSON G. (eds.). Postharvest handling of fresh vegetables. Canberra: Australian Center for International Agricultural Research. ACIAR Proceedings 101, p. 44-48.

NAVAZIO JP; STAUB JE. 1994. Effects of soil moisture, cultivar, and postharvest handling on pillowy fruit disorder in cucumber. Journal of the American Society for Horticultural Science 119: 1234-1242.

NUNES GHS; SANTOS JÚNIOR JJ; ANDRADE FV; BEZERRA NETO F; MENEZES JB; PEREIRA EWL. 2005. Desempenho de híbridos de melão do grupo inodorus em Mossoró. Horticultura Brasileira 23: 90-93.

OBANDO J; FERNÁNDEZ-TRUJILLO JP; MARTÍNEZ JA; ALARCÓN AL; EDUARDO I; ARÚS P; MONFORTE AJ. 2008. Identification of melon fruit quality quantitative trait loci using near-isogenic lines. Journal of the American Society for Horticultural Science 133: 139-151.

OBANDO J; MIRANDA C; JOWKAR MM; MORENO E; SOURI MK; MARTÍNEZ JA; ARÚS P; GARCÍA-MAS J; MONFORTE AJ; FERNÁNDEZ-TRUJILLO JP. 2007. Creating climacteric melon fruit from nonclimacteric parentals: Postharvest quality implications. In: RAMINA A; CHANG C; GIOVANNONI J; KLEE H; PERATA P; WOLTERING E. (eds.). Advances in plant ethylene research. Proceedings of the 7th international symposium on the plant hormone ethylene. Dordrecht: Kluwer Academia Pub. Group p. 197-205.

OBANDO-ULLOA J; MORENO E; GARCÍAMAS J; NICOLAI B; LAMMERTYN J; 
MONFORTE AJ; FERNÁNDEZ-TRUJILLO

JP. 2008 Climacteric or non-climacteric behavior in melon fruit 1 . Aroma volatiles. Postharvest Biology and Technology 48: 27-37.

PÉRIN C; GÓMEZ-JIMÉNEZ M; HAGEN L; DOGIMONT C; PECH JC; LATCHÉ A; PITRAT M; LELIĖVRE JM. 2002. Molecular and genetic characterization of a non-climacteric phenotype in melon reveals two loci conferring altered ethylene response in fruit. Plant Physiology 129: 300-309.

RICHARDS GM; BEUCHAT LR. 2005. Infection of cantaloupe rind with Cladosporium cladosporioides and Penicillium expansum, and associated migration of Salmonella poona into edible tissues. International Journal of Food Microbiology 103: 1-10.

SALES R; SOARES SPF; AMARO J; NUNES GHS; MIRANDA VS. 2004. Quality of melon exported through the port of Natal, Brazil. Horticultura Brasileira 22: 98-100.

SAN BAUTISTA A; LÓPEZ-GALARZA S; RUBIO JF; BONO MS; LAZA P; PALAU
V; SOLÍS G; PASCUAL B; ALAGARDA J; MAROTO JV. 2004. Efecto de diversas dosis de riego sobre la producción, calidad, incidencia de fisiopatías, y parámetros del desarrollo en cultivo protegido de melón. Agrícola Vergel 275: 562-569.

SERCE S; NAVAZIO JP; GOKCE AF; STAUB JE. 1999. Nearly isogenic cucumber genotypes differing in leaf size and plant habit exhibit differential response to water stress. Journal of the American Society for Horticultural Science 124: 358-365.

SNOWDON AL. 1991 A colour atlas of postharvest diseases and disorders of fruits and vegetables: vegetables. London: Wolfe Scientific Ltd. 216p.

SOUZA M; MENEZES JB; ALVES RE. 1994. Postharvest technology and productivity of melons in the State of Rio Grande do Norte. Horticultura Brasileira 12: 188-190.

STAUB JE; NAVAZIO JP. 1993. Temperature and humidity affect pillowy fruit disorder in cucumber. HortScience 28: 822-823.

VEGH1-INRA. 2005. Cucurbit diseases.
Cladosporium cucumerinum Ell. et Arthur Scolichotrichum melophthorum Prill. et Delacr. Available in http://www.inra.fr/hyp3/ pathogene/6clacuc.htm

YANG B; SHIPING T; HONGXIA L; JIE Z; JIANKANG C; YONGCAI L; WEIYI Z. 2003. Effect of temperature on chilling injury, decay and quality of Hami melon during storage. Postharvest Biology and Technology 29: 229-232.

ZHENG, SY, WOLFF DW. 2000. Ethylene production, shelf-life and evidence of RFLP polymorphisms linked to ethylene genes in melon (Cucumis melo L.). Theoretical and Applied Genetics 101: 613-624.

ZITTER TA. 1986. Scab of cucurbits. Available in http://vegetablemdonline.ppath.cornell.edu/ factsheets/Cucurbit_Scab.htm.

ZITTER TA; HOPKINS DL; THOMAS CE. 2004. Plagas y enfermedades de las cucurbitáceas. Madrid: The American Phytophatological Society. Ed. Mundi-Prensa. 88p. 